\title{
Immunological findings in blood and bronchoalveolar lavage fluid in chronic bronchitis patients with recurrent infectious exacerbations
}

\author{
I. Qvarfordt*, G.C. Riise**, S. Larsson**, G. Almqvist+, J. Rollof+, T. Bengtsson+, B.A. Andersson++
}

Immunological findings in blood and bronchoalveolar lavage fluid in chronic bronchitis patients with recurrent infectious exacerbations. I. Qvarfordt, G.C. Riise, S. Larsson, G. Almqvist, J. Rollof, T. Bengtsson, B.A. Andersson. OERS Journals Ltd 1998.

ABSTRACT: Bronchial infections are common in smokers and seem to be related to the presence of chronic bronchitis (CB). Why only some smokers develop repeated bronchial infections is not known. The aim of this study was to screen for immunological changes associated with disease in patients with $\mathrm{CB}$ and recurrent infectious exacerbations compared to asymptomatic smokers.

Sixteen smokers with stable CB and recurrent infectious exacerbations, and 18 asymptomatic smokers, all without any immunomodulating treatment, underwent bronchoscopy and bronchoalveolar lavage (BAL). Smoking history and current smoking status were comparable. Serum levels of immunoglobulin (Ig)A, IgM, IgG and IgG subclasses were measured. Blood and BAL lymphocyte phenotypes and proliferative responses of peripheral blood mononuclear cells (PBMCs) to various stimulators were analysed. Unstimulated and tetanus toxoid-stimulated production of cytokines in PBMC cultures was measured. Natural killer (NK-) cell activity was analysed.

A significantly $(\mathrm{p}<0.05)$ lower level of $\operatorname{IgG}_{3}$ was found in the $\mathrm{CB}$ group, and a significantly $(\mathbf{p}<0.01)$ higher proliferative response of PBMCs was found in the CB group after stimulation with diphtheria toxoid. Detectable levels of interleukin (IL)-6, tumour necrosis factor- $\alpha$ (TNF- $\alpha)$ and interferon- $\gamma$, but not of IL-2, IL-4 or transforming growth factor- $\beta 2$, were found in supernatants from cultured cells in both study groups. Stimulated TNF- $\alpha$ production was significantly $(\mathbf{p}<0.05)$ higher in the CB group. NK-cell activity did not differ significantly between the study groups. There were no major differences between the groups in lymphocyte subpopulations in blood or BAL.

In conclusion, no major alterations in the analysed indices of cell-mediated and humoral immunity were found in patients with chronic bronchitis prone to recurrent infectious exacerbations when compared with asymptomatic smoking controls.

Eur Respir J 1998; 11: 46-54.
Depts of *Infectious Diseases, **Pulmonary Medicine and Allergology, and ${ }^{++}$Clinical Immunology, Sahlgrenska University Hospital, Göteborg, Sweden, ${ }^{+}$Clinical Research and Development, Astra Draco AB, Lund, Sweden.

Correspondence: I. Qvarford

Dept of Infectious Diseases

Sahlgrenska University Hospital/Östra

S-416 85

Göteborg

Sweden

Fax: 004631847813

Keywords: Bronchoalveolar lavage

chronic bronchitis

flow cytometry

infectious exacerbations

smoking

Received: March 211997

Accepted after revision August 291997
Tobacco smoking induces profound immunological and inflammatory changes, both in the airways and systemically. Smoking impairs host defences and increases susceptibility to infection $[1,2]$.

The literature on the effects of smoking on the immune system is extensive and has been reviewed by several authors [2-4]. Evidence of a considerable influence on both humoral and cell-mediated immunity has been presented. Decreased serum immunoglobulin (Ig) levels, mainly IgG, have been reported in smokers [5, 6]. Data concerning immediate skin reactivity to common allergens $[7,8]$ as well as specific antibody responses to inhaled antigens [9] and vaccinations [10], indicate depressed immune responses in smokers. There are several reports of decreased activity of natural killer (NK-) cells, both from peripheral blood $[11,12]$ and the lung [13]. Results from functional studies of circulating T-lymphocytes are conflicting, with reports of increased [14], unchanged [15] and decreased [16, 17] responses to mitogenic stimulation in vitro. Alterations in immunoregulatory T-lymphocyte subsets with a decreased fraction of helper/inducer and an increased fraction of cytotoxic/suppressor cells have been reported, both locally in the lung [18], and in the peripheral circulation [19, 20].

Bronchial infections are common in smokers [2], but why only some smokers develop problems with repeated bronchial infections is largely unknown. Hypothetically, smokers prone to bronchial infections might differ immunologically from smokers without this disposition. To our knowledge, there are no studies addressing this issue in which smoking habits of study and control groups have been taken fully into account.

Since the disposition for bronchial infections in smokers seems to be related to the presence of chronic bronchitis (CB) [21], a state of chronic mucus hypersecretion [22], and appear in the form of recurrent infectious exacerbations, patients with $\mathrm{CB}$ prone to infectious exacerbations were chosen for the study group. We decided to analyse most of the immunological parameters known or thought 
to be influenced by smoking, to investigate whether patients with CB and recurrent infections differed from asymptomatic smokers with comparable smoking habits.

\section{Materials and methods}

\section{Design}

The study was a cross-sectional, parallel group study investigating different indices of airway and systemic immunity in patients with $\mathrm{CB}$ and recurrent infectious exacerbations compared with asymptomatic smokers. The subjects were recruited from patient files at the Department of Pulmonary Medicine and by advertisement in a daily newspaper. A medical examination, a lung function test, and blood sampling for haematology and clinical chemistry took place at one visit. Approximately 2 weeks later, venous blood for immunological analyses was drawn and fibreoptic bronchoscopy with bronchoalveolar lavage (BAL) performed. The study was performed between May 1993 and June 1994.

The study was approved by the Ethics Committee at the University of Göteborg. The subjects gave their consent after both written and oral information.

\section{Subjects}

Eighteen asymptomatic control subjects were studied. All were current smokers for more than 10 yrs consuming at least 10 cigarettes $\cdot$ day $^{-1}$ without fulfilling the American Thoracic Society (ATS)-defined criteria of CB [22]. All had normal lung function defined as forced expiratory volume in one second $\left(\mathrm{FEV}_{1}\right)>80 \%$ of predicted. In addition, 16 patients with symptoms of CB as defined by ATS [22], i.e. chronic or recurrent productive cough on most days for a minimum of 3 months in the year during the past $2 \mathrm{yrs}$, were studied. Co-existing chronic airway obstruction defined as FEV1 $<80 \%$ pred was allowed. All patients were current smokers for more than $10 \mathrm{yrs}$, consuming at least 10 cigarettes $\cdot$ day $^{-1}$. In addition, they all had a history of two or more infectious exacerbations during the past 12 months as defined by Boman et al. [23]. The total number of exacerbations during the past 2 yrs was recorded.

No subject was allowed to use $\mathrm{N}$-acetylcysteine (NAC) or antihistamines or to undergo vaccination or other immunomodulating treatment within 4 weeks prior to the first investigation. No glucocorticosteroid treatment (oestrogen included), whether oral, for inhalation, dermal or nasal, or other immunosuppressant treatment was allowed within 3 months prior to the first investigation. All subjects were to be free of symptoms of infectious respiratory disease 4 weeks prior to the investigation. All subjects were to be 35-65 yrs of age. Subject demographic and clinical data are presented in table 1.

Criteria for exclusion were: baseline FEV $1<45 \%$ pred; a postbronchodilator increase in FEV $1>15 \%$ pred abnormal chest radiograph; bronchial hypersecretion caused by other known active pulmonary diseases such as sarcoidosis or cystic fibrosis; known immunodeficiency; $\alpha 1$-antitrypsin deficiency; or a history of asthma. Patients with
Table 1. - Demographic and clinical data

\begin{tabular}{lccc}
\hline & $\begin{array}{c}\text { Asymptomatic } \\
\text { smokers }\end{array}$ & $\begin{array}{c}\text { CB with } \\
\text { exacerbations }\end{array}$ & p-value \\
\hline Subjects n & 18 & 16 & \\
Age yrs & $45(35-58)$ & $53(38-63)$ & 0.007 \\
FEV1\% pred & $93(81-114)$ & $88(62-124)$ & Ns \\
Pack-years & $28(15-57)$ & $29(16-44)$ & Ns \\
$\begin{array}{l}\text { Current smoking } \\
\quad \text { cigarettes·day-1 }\end{array}$ & $20(10-30)$ & $20(10-30)$ & NS \\
$\begin{array}{l}\text { Gender Male/Female } \\
\text { Duration of CB yrs }\end{array}$ & $7 / 11$ & $4 / 12$ & NS \\
Exacerbations in 2 yrs & 0 & $8(4-26)$ & \\
\hline
\end{tabular}

Values are presented as median with range in parenthesis. CB: chronic bronchitis; ss: nonsignificant.

known atopy were also excluded, as were patients with concurrent severe diseases of any kind as judged by the investigators.

Ventilatory lung function (FEV1\% pred) was measured with a Vitalograph Alpha (Vitalograph Ltd., Buckingham, UK) in a standardized manner according to the directions of the European Coal and Steel Community [24].

\section{Clinical chemistry and haematology}

Five millilitres of venous blood was drawn at the first visit for analysis of haemoglobin, platelet count, leucocytes (total and differential count) and C-reactive protein. The Sahlgrenska University Hospital laboratory's instructions for handling of samples and its reference ranges for normality were used.

\section{Fibreoptic bronchoscopy}

Immediately preceding bronchoscopy, $90 \mathrm{~mL}$ of venous blood for immunological analyses was drawn.

Premedication was given as oral diazepam (5-10 mg) together with $0.5-1 \mathrm{~mL}$ morphine-scopolamine $(10 \mathrm{mg}$. $\left.\mathrm{mL}^{-1}+0.4 \mathrm{mg} \cdot \mathrm{mL}^{-1}\right)$ i.m. $45 \mathrm{~min}$ before bronchoscopy. Local anaesthesia of the oropharynx was given as $1 \%$ tetracaine sprayed by a deVilbiss aerosol device (de Vilbiss Ltd., Heston, UK) ( $\sim \mathrm{mL})$, followed by additional (4-5 $\mathrm{mL}$ ) instillation of tetracaine into the larynx. All bronchoscopies were performed transorally by one of two experienced bronchoscopists, and with the subject in the supine position.

\section{Bronchoalveolar lavage}

With the bronchoscope wedged in a middle lobe bronchus, BAL was performed by instilling $2 \times 100 \mathrm{~mL}$ sterile phosphate-buffered saline (PBS) at $37^{\circ} \mathrm{C}$, and immediately aspirating the fluid after each instillation. The aspirated BAL fluid was pooled in a siliconized glass container and immediately transported on ice to the Department of Clinical Immunology for analysis.

Recovery was measured, and the fluid filtered through a nylon web with a pore size of $100 \mu \mathrm{m}$ for retention of mucus and cell debris. The lavage fluid was then centrifuged at $250 \times \mathrm{g}$ for $10 \mathrm{~min}$ at $+4^{\circ} \mathrm{C}$. The supernatant was 
separated, and the cell-pellet was resuspended in PBS. The total number of cells in BAL fluid from the first eight asymptomatic smokers and the first four CB patients was determined with a haematological cell counter (Sysmex S300, TOA Medical Electronics Co Ltd, Kobe, Japan). We noted, however, that the values from these determinations did not correspond with determinations using a haemocytometer, probably due to debris in the BAL samples. The remainder of the determinations, 10 from the asymptomatic smoker (AS) and 12 from the CB group, were therefore performed using a haemocytometer. Cell viability was estimated by means of trypan blue exclusion. Calculation of cell differentials was done on cytocentrifuged preparations (Cytospin 2; Shandon Southern Products Ltd., Runcorn, UK) stained with May-Grünwald-Giemsa and after counting of 1,000 cells.

\section{Assay of serum immunoglobulins}

The content of $\operatorname{IgG}, \operatorname{IgM}$ and $\operatorname{Ig} \mathrm{A}$ as well as of the $\mathrm{IgG}$ subclasses in serum was assessed by radial immunodiffusion, using class specific polyclonal rabbit antihuman IgG, IgM and IgA (Dakopatts a/s, Glostrup, Denmark) and monoclonal subclass specific antibodies to $\mathrm{IgG}_{1}, \mathrm{IgG}_{2}$, $\mathrm{IgG}_{3}$ and $\mathrm{IgG}_{4}$ (Oxoid Unipath Ltd, Hampshire, UK). The concentration of the Ig classes and subclasses was expressed in $\mathrm{g} \cdot \mathrm{L}^{-1}$, by comparison with a standard. The class reference ranges of the Department of Clinical Immunology (IgG: 7.6-22.1, IgM: 0.5-3.4 and IgA: 0.2-2.8 g. $\mathrm{L}^{-1}$ ) and the IgG subclass reference ranges published by Oxelus [25] $\left(\mathrm{IgG}_{1}: 4.22-12.92, \mathrm{IgG}_{2}: 1.17-7.47, \mathrm{IgG}_{3}: 0.41-1.29\right.$ and $\left.\mathrm{IgG}_{4}:<2.91 \mathrm{~g} \cdot \mathrm{L}^{-1}\right)$ were used.
Flow cytometry analysis of lymphocytes in blood and $B A L$

In order to investigate the distribution in blood and BAL of major lymphocyte subsets (T-, B- and NK-cells, memory and unprimed T-cells, helper/inducer and cytotoxic/suppressor T-cells) and their expression of activation markers and cell adhesion molecules, subpopulations of lymphocytes were determined by flow cytometry. The sam-ples were stained with combinations of murine monoclonal antibodies, directly conjugated with fluorochromes (fluorescein isothiocyanate, phycoerythrin, Rphycoerythrin-Cy5 or Tri-color). Whole blood (with ethylenediamine tetra-acetic acid (EDTA) as anticoagulant and in a volume corresponding to about $5 \times 10^{5}$ cells sample $\left.^{-1}\right)$ and BAL cells $\left(1 \times 10^{5}\right.$ cells $\cdot$ sample $\left.^{-1}\right)$ were incubated at $4^{\circ} \mathrm{C}$ for $15 \mathrm{~min}$ with antibodies in the concentrations recommended by the manufacturer. The different monoclonal antibodies used are listed in table 2.

Cell analysis was done on a FACScan flow cytometer (Becton-Dickinson, Mountain View, CA, USA), calibrated with CALIBRITE $®$ beads (Becton-Dickinson) and Auto- COMP® software (Becton-Dickinson). A lymphocyte gate was set manually according to the location in the forward scatter versus side scatter diagram. Negative isotype controls (Dakopatts a/s) were used to set quadrant markers which delineated positive fluorescent staining from non-antigen specific staining. Dot plots and quadrant statist- ics from three-colour analysis were generated by Lysis II software (Becton-Dickinson). The absolute number of blood lymphocytes was determined using a haematological cell counter (Sysmex-K1000; TOA Medical Electronics Co). In the majority of the BAL samples, it

Table 2. - Murine monoclonal antibodies against cell surface antigens used for staining of blood and bronchoalveolar lavage cells in flow cytometry

\begin{tabular}{llll}
\hline Surface antigen & Cell population/antigen characteristic & Fluorochrome & Manufacturer \\
\hline CD3 & T-lymphocyte & Fluoroscein isothiocyanate & Dakopatts a/s, * \\
CD3 & T-lymphocyte & R-phycoerytrin-Cy5 & Dakopatts a/s* \\
CD5 & T-lymphocyte & Phycoerytrin & Dakopatts a/s* \\
TCR $\alpha \beta$ & T-cell antigen receptor $\alpha \beta$ & Fluorescein isothiocyanate & Becton-Dickinson $^{+}$ \\
TCR $\delta$ & T-cell antigen receptor $\gamma \delta$ & Fluorescein isothiocyanate & Becton-Dickinson $^{+}$ \\
45RA & Unprimed cell & Fluorescein isothiocyanate & Dakopatts a/s* \\
45R0 & Memory cell & Phycoerytrin & Dakopatts a/s* \\
45RB & Subset of T-cells, B-cells & Fluorescein isothiocyanate & Dakopatts a/s* \\
CD4 & Helper/inducer cell & Phycoerytrin & Dakopatts a/s* \\
CD4 & Helper/inducer cell & R-phycoerytrin-Cy5 & Dakopatts a/s* \\
CD8 & Cytotoxic/suppressor cell & Phycoerytrin & Dakopatts a/s* \\
CD8 & Cytotoxic/suppressor cell & R-phycoerytrin-Cy5 & Dakopatts a/s* \\
HLA-DR & Activated cell, transplantation antigen & Fluorescein isothiocyanate & Dakopatts a/s* \\
HLA-DR & Activated cell, transplantation antigen & Phycoerytrin & Becton-Dickinson \\
CD69 & Activated cell, early activation marker & Phycoerytrin & Becton-Dickinson ${ }^{+}$ \\
CD25 & Activated cell, IL-2 receptor & Fluorescein isothiocyanate & Dakopatts a/s* \\
CD2 & Adhesion molecule & Phycoerytrin & Dakopatts a/s* \\
CD11b & Adhesion molecule & Phycoerytrin & Dakopatts a/s* \\
CD11c & Adhesion molecule & Fluorescein isothiocyanate & Dakopatts a/s* \\
CC18 & Adhesion molecule & Fluorescein isothiocyanate & Dakopatts a/s* \\
CD54 & Adhesion molecule & Phycoerytrin & Serotec \\
CD56 & NK-cells, subset of T-cells & Phycoerytrin & Becton-Dickinson $^{*}$ \\
CD56 & NK-cells, subset of T-cells & Tri-color & Caltag Lab. Inc* \\
CD19 & B-cells & R-phycoerytrin-Cy5 & Dakopatts* \\
\hline
\end{tabular}

*: Glostrup, Denmark; +: Mountain View, CA, USA; \#: Oxford, UK; *: South San Francisco, CA, USA. CD: cluster of differentiation; TCR: T-cell receptor; HLA-DR: human leucocyte antigen DR gene cluster product; IL-2: interleukin 2; NK: natural killer. 
was difficult to discriminate events representing lymphocytes from events due to debris in the forward scatter versus side scatter diagram. To compensate for this, all percentages of lymphocyte subpopulations from BAL and blood from each individual were divided by the sum of the percentages of CD3+, CD19+ and CD3-56+. This sum inclu-des T-cells, B-cells and NK-cells and represents all major lymphocyte populations. These adjusted values were then used in all calculations. One BAL sample from a control subject contained mainly cell debris, probably due to accidental lysis of the lymphocytes in the sample while lysing contaminating erythrocytes in the preparation for flow cy-tometry. The result of the analysis of this sample was therefore discarded.

Results for each subpopulation were expressed in blood as percentage of lymphocytes and as number of cells $\times$ $10^{9} \cdot \mathrm{L}^{-1}$, and in BAL as percentage of lymphocytes.

\section{Blood lymphocyte stimulation and proliferation assay}

Mononuclear cells from blood collected in heparinized tubes were prepared by centrifugation on Ficoll-Hypaque (Lymphoprep; Nycomed Pharma a/s, Oslo, Norway) at $827 \times \mathrm{g}$ for $10 \mathrm{~min}$ at room temperature. A total of $1 \times 10^{5}$ cells in a volume of $200 \mu \mathrm{L}$ was put in the wells of a microtiter plate with round-bottom wells (Nuclon; Nunc a/s, Roskilde, Denmark). Triplicates of each of the following stimulators were added: tetanus toxoid (final concentration: $10 \mu \mathrm{g} \cdot \mathrm{mL}^{-1}$; SBL Vaccin Ltd., Stockholm, Sweden), staphylococcus enterotoxin A (SEA; final concentration: 5 ng. $\mathrm{mL}^{-1}$; Toxin Technology, Inc., Sarasota, FL, USA), purified protein derivative (PPD; $10 \mu \mathrm{g} \cdot \mathrm{mL}^{-1}$; Statens Seruminstitut, Copenhagen, Denmark), phytohaemagglutinin (PHA; final concentration: $10 \mu \mathrm{g} \cdot \mathrm{mL}^{-1}$; Wellcome Foundation Ltd., Beckenham, UK), diphtheria toxoid (100 $\left.\mu \mathrm{g} \cdot \mathrm{mL}^{-1} ; \mathrm{SBL}\right)$ and monoclonal anti-CD3 (125 $\mathrm{ng} \cdot \mathrm{mL}^{-1}$; Ortho Diagnostic Systems, Inc., Raritan, NJ, USA). A triplicate of wells without any stimulator was used as a negative control. The cells were then incubated in Iscoves's medium supplemented with $5 \times 10^{-5}$ M 2-mercaptoethanol, $10 \%$ human AB-serum (Sera-Lab, Sussex, UK) and gentamicin (final concentration: $100 \mathrm{U} \cdot \mathrm{mL}^{-1}$; Schering-Plough Int., Kenilworth, NJ, USA), in $5 \% \mathrm{CO}_{2}$ at $37^{\circ} \mathrm{C}$ for $48 \mathrm{~h}$. A sample of $150 \mu \mathrm{L}$ of culture superna- tant was removed from each well and frozen at $-70^{\circ} \mathrm{C}$ for later analysis of cytokine content. Then, $150 \mu \mathrm{L}$ of fresh medium and stimulator were added and the plate was incubated for another $24 \mathrm{~h}$. ${ }^{3} \mathrm{H}$-thymidine (Amersham International plc, Amersham, UK) was then added and the plate was incubated over night. The cells were harvested (96-well cell harvester, INOTECH, Dottikon, Switzerland) and radioactivity measured as counts per minute (cpm) using a $\beta$-counter Matrix $_{96}$; Packard Instrument Co., Inc., Chicago, IL, USA). Results were presented as stimulatory index $(\mathrm{SI})=\mathrm{cpm}$ of stimulated cells/cpm of unstimulated cells.

\section{Cytokine analyses}

Cytokines were analysed in supernatants from cells stimulated with tetanus toxoid. Commercially available kits were used according to the instructions of the manufacturer (R\&D Systems Inc., Minneapolis, MN, USA) for the determination of interleukin (IL)-4, tumour necrosis factor- $\alpha$ (TNF- $\alpha)$ and transforming growth factor- $\beta 2$ (TGF$\beta 2)$.

Interferon- $\gamma($ IFN- $\gamma$ ) was determined with a sandwich enzyme-linked immunosorbent assay (ELISA) technique in which a polystyrene microtitre plate (Maxisorb, Nunc $\mathrm{a} / \mathrm{s}$ ) was coated with a monoclonal antibody against IFN- $\gamma$ (Chromogenix AB, Mölndal, Sweden) and incubated over night at $4^{\circ} \mathrm{C}$. After washing and blocking with $1 \%$ bovine serum albumin (BSA) in PBS, the sample and standard (recombinant human IFN- $\gamma$, Genzyme Corporation, Cambridge, MA, USA) was added and the plate was incubated for $2 \mathrm{~h}$ at $37^{\circ} \mathrm{C}$. After washing, biotinylated anti-IFN- $\gamma$ (Chromogenix $\mathrm{AB}$ ) was added and the plate was incubated over night at $4^{\circ} \mathrm{C}$. After washing, alkaline phosphatase conjugated extravidin (Sigma Chemical Co, St Louis, MO, USA) was added and the plate was incubated for $1 \mathrm{~h}$ at room temperature. After washing, substrate for alkaline phosphatase extravidin (Sigma Chemical Co) dissolved in diethanolamine buffer was added and the absorbance at $405 \mathrm{~nm}$ was recorded using a photometer (Multiscan ${ }^{\circledR}$ BICHROMATIC, Labsystems Oy, Helsinki, Finland).

IL-2 was determined as in a previously described bioassay using the cytotoxic T-lymphocyte line (CTLL)-2 cell line which is dependent on IL-2 for its proliferation [26].

IL-6 was determined as in a previously described bioassay using the B9 subclone of the cell line B13.29 [27].

\section{Assay of blood NK-cell activity}

NK-cell activity was assayed as previously described [28]. NK-cell activity was expressed as the percentage of target cell lysis at an effector to target cell ratio of 5:1.

\section{Statistical analysis}

A StatView® 4.5 (Abacus Concepts, Berkeley, CA, USA) software package was used for the statistical analysis. Since most of the data did not show a normal distribution, data are presented as median and range unless otherwise stated. For comparisons between groups, a Wilcoxon rank sum test or a Fisher's exact test was performed for unpaired, and a Wilcoxon signed rank test for paired observations. All tests were two-tailed and $p$-values $<0.05$ were accepted as significant. A Spearman rank correlation coefficient was calculated to investigate correlations between clinical variables.

\section{Results}

\section{Haematology, clinical chemistry and serum immunoglob- ulins}

There were no significant differences in haemoglobin level, platelet and total or differential leucocyte counts between the groups. No abnormal values of clinical significance were observed. All measurements of C-reactive protein were below the detection limit, i.e. $<10 \mathrm{mg} \cdot \mathrm{L}^{-1}$ (data not shown). 
Table 3. - Serum immunoglobulins

\begin{tabular}{llclc}
\hline & $\begin{array}{c}\text { Asymptomatic } \\
\text { smokers } \\
(\mathrm{n}=18)\end{array}$ & $\begin{array}{c}\text { CB with } \\
\text { exacerbations } \\
(\mathrm{n}=16)\end{array}$ & $\mathrm{p}$-value \\
\hline $\mathrm{IgG}$ & $\mathrm{g} \cdot \mathrm{L}^{-1}$ & $11.2(7.1-15.1)$ & $9.9(6.4-14.0)$ & $\mathrm{NS}$ \\
$\mathrm{IgA}$ & $\mathrm{g} \cdot \mathrm{L}^{-1}$ & $2.8(1.7-4.2)$ & $2.4(1.0-4.8)$ & $\mathrm{NS}$ \\
$\mathrm{IgM}$ & $\mathrm{g} \cdot \mathrm{L}^{-1}$ & $1.9(1.5-4.4)$ & $1.9(0.8-4.7)$ & $\mathrm{NS}$ \\
$\mathrm{IgG}$ & $\mathrm{g} \cdot \mathrm{L}-1$ & $6.1(2.9-7.8)$ & $5.7(3.2-7.8)$ & $\mathrm{NS}$ \\
$\mathrm{IgG}_{2}$ & $\mathrm{~g} \cdot \mathrm{L}^{-1}$ & $2.3(1.1-4.3)$ & $2.2(0.5-4.0)$ & $\mathrm{NS}$ \\
$\mathrm{IgG}_{3}$ & $\mathrm{~g} \cdot \mathrm{L}^{-1}$ & $0.8(0.1-1.2)$ & $0.5(0.1-2.2)$ & 0.03 \\
$\mathrm{IgG}_{4}$ & $\mathrm{~g} \cdot \mathrm{L}^{-1}$ & $0.2(0.1-1.2)$ & $0.3(0.1-0.6)$ & $\mathrm{N}$
\end{tabular}

Values are presented as median with range in parenthesis. Ig: immunoglobulin; CB: chronic bronchitis; Ns: nonsignificant.

The results of the serum immunoglobulin analyses are presented in table 3 . No subjects with IgA or IgM isotype deficiencies were detected. Eleven $(32 \%)$ of the 34 subjects were deficient in total IgG or one or more IgG subclasses, eight out of $16(50 \%)$ in the $\mathrm{CB}$ group and three out of $18(17 \%)$ in the AS group. This difference was not statistically significant. Three subjects, two in the CB group and one in the AS group, had a deficiency in more than one IgG subclass resulting in a mild deficiency in total IgG. Four individuals, three in the $\mathrm{CB}$ group and one in the AS group had a minor $\operatorname{IgG}_{1}$ deficiency. Only one, in the $\mathrm{CB}$ group, had a low $\mathrm{IgG}_{2}$ value. The most common IgG subclass deficiency was $\operatorname{IgG}_{3}$, with more individuals with this deficiency in the CB group (seven out of 16, $44 \%$ ) than in the AS group (two out of $18,11 \%$ ). This difference was not statistically significant. However, the level of $\mathrm{IgG}_{3}$ differed significantly $(\mathrm{p}=0.03)$ between the groups, with a lower level in the $\mathrm{CB}$ group.

In view of the fact that $\mathrm{IgG}_{3}$ differed significantly between the two groups, we investigated the possible correlation between $\mathrm{IgG}_{3}$ and the number of exacerbations during the past 2 yrs, but found none.

\section{Bronchoalveolar lavage}

Volume recovery, cell viability, cell concentration, differential cell counts and albumin levels were determined and data are presented in table 4. Recovery was slightly lower in the CB group but the difference was not statis-

Table 4. - Recovery, cell viability and cell populations in bronchoalveolar lavage

\begin{tabular}{lccc}
\hline & $\begin{array}{c}\text { Asymptomatic } \\
\text { smokers } \\
(\mathrm{n}=18)\end{array}$ & $\begin{array}{c}\text { CB with } \\
\text { exacerbations } \\
(\mathrm{n}=16)\end{array}$ & p-value \\
\hline Volume recovered \% & $45(23-58)$ & $40(20-60)$ & NS \\
Viability \% & $80(59-94)$ & $70(38-89)$ & 0.03 \\
Cell concentration* & $37(19-91)$ & $29(18-54)$ & Ns \\
$10^{4}$ cells·mL-1 & $60(23-94)$ & $47(24-96)$ & NS \\
Albumin mg.L-1 & $95(82-97)$ & $95(87-99)$ & NS \\
Macrophages \% & $3.5(1-14)$ & $4(1-7)$ & NS \\
Lymphocytes \% & $1(0-5)$ & $1(0-4)$ & NS \\
Neutrophils \% & $1(0-3)$ & $0(0-3)$ & NS \\
Eosinophils \% & & & \\
\hline
\end{tabular}

Values are presented as median with range in parenthesis. *: In the asymptomatic smokers group $n=10$, in the $C B$ group $n=12$. $\mathrm{CB}$ : chronic bronchitis; Ns: nonsignificant. tically significant. Cell viability was significantly lower ( $70 \%$ versus $80 \%, \mathrm{p}=0.03$ ) in the $\mathrm{CB}$ group. Reliable values of cell concentrations were obtained in 12 and 10 subjects in the CB and AS groups, respectively (see Materials and methods). There were no significant differences between the groups in cell concentration or the fractions of macrophages, lymphocytes, eosinophils or neutrophils. Albumin levels in BAL fluid were comparable.

\section{Flow cytometry of blood and BAL lymphocytes}

The following lymphocyte subpopulations were characterized and the mean percentages (blood and BAL) and absolute numbers (blood) for each study group determined: T-, B- and NK-cells, T-cells with $\alpha \beta$ or $\gamma \delta$ antigen receptors, memory and unprimed T-cells, helper/inducer and cytotoxic/suppressor T-cells, T-cells expressing activation markers and cell adhesion molecules, NK-cells expressing human leucocyte antigen DR (HLA-DR) and cell adhesion molecules (table 2).

In blood the mean counts of the different subpopulations were similar in both groups and no significant differences between the groups could be detected in any subset (data not shown).

In the BAL samples the number of cells analysed varied between 10,000 and 50,000. For markers with a positive fraction of $\partial 11 \%$ the median number of positive cells was $<50$. Since this results in a minimal theoretical variation of $14 \%$, comparisons between groups were only performed for markers with a positive fraction of $>11 \%$. These included T-cells, T-memory cells, T-cells with $\alpha \beta$ antigen receptor, helper/inducer and cytotoxic/suppressor T-cells, T-cells expressing the activation markers DR or CD69 and the adhesion molecules CD2 or CD18. Of these, the fractions of $\mathrm{CD} 3+45 \mathrm{RB}+$ and $\mathrm{CD} 4+5+$ (helper/inducer cell) were significantly $(\mathrm{p}<0.05)$ lower in the $\mathrm{CB}$ group. For all other subpopulations, no significant differences between the groups in the mean percentages were found (data not shown).

\section{Comparison of lymphocyte subpopulations in BAL and blood}

To analyse possible differences in the distribution of major lymphocyte subpopulations in BAL compared to blood, the fractions in BAL and blood of 10 selected subpopulations were compared. Data from 33 complete pairs of observations were used for this comparison. Results are presented in table 5. The differences between BAL and blood were large and highly significant for most subpopulations, the only exception being IL-2 receptor positive Tcells $(\mathrm{CD} 3+25+)$. The fractions of T-cells, T-memory cells, T-cytotoxic cells and two populations of activated T-cells were, on average, larger in BAL than in blood. The fractions of B-cells, unprimed or "naive" T-cells and T-helper cells were on average smaller in BAL than in blood. The T-helper/T-cytotoxic $(\mathrm{TH} / \mathrm{TC})$ ratio was significantly $(\mathrm{p}=$ 0.0003 ) lower in BAL (geometric mean 1.1, coefficient of variation 0.8$)$, than in blood $(2.0,0.3)$.

To investigate a possible difference between the asymptomatic smokers and the $\mathrm{CB}$ patients in the BAL to blood lymphocyte subset composition, we created BAL/blood 
Table 5. - Comparison of lymphocyte subpopulations in BAL and blood

\begin{tabular}{|c|c|c|c|c|}
\hline & $\begin{array}{l}\text { Surface } \\
\text { antigen }\end{array}$ & $\begin{array}{l}\text { BAL } \\
(n=33)\end{array}$ & $\begin{array}{l}\text { Blood } \\
(n=33)\end{array}$ & p-value \\
\hline \multicolumn{5}{|l|}{ Cell population* } \\
\hline T-lymphocyte & CD3+ & $92 \pm 5$ & $80 \pm 7$ & $<0.0001$ \\
\hline B-lymphocyte & CD19+ & $3 \pm 4$ & $13 \pm 7$ & $<0.0001$ \\
\hline NK-cell & CD3-56+ & $5 \pm 3$ & $7 \pm 3$ & $<0.001$ \\
\hline \multicolumn{5}{|l|}{$\begin{array}{l}\text { T-lymphocyte } \\
\text { subpopulations }\end{array}$} \\
\hline Unprimed cell & CD3+45RA+ & $6 \pm 7$ & $33 \pm 20$ & $<0.0001$ \\
\hline Memory cell & CD3+45R0+ & $93 \pm 12$ & $61 \pm 13$ & $<0.0001$ \\
\hline Helper/inducer cell & CD3+4+ & $49 \pm 18$ & $65 \pm 8$ & $<0.001$ \\
\hline $\begin{array}{l}\text { Cytotoxic/ } \\
\text { suppressor cell }\end{array}$ & $\mathrm{CD} 3+8+$ & $46 \pm 20$ & $32 \pm 7$ & $<0.001$ \\
\hline Activated cell & CD3+DR+ & $23 \pm 15$ & $13 \pm 9$ & $<0.01$ \\
\hline Activated cell & $\mathrm{CD} 3+69+$ & $48 \pm 23$ & $3 \pm 8$ & $<0.0001$ \\
\hline Activated cell & CD3+25+ & $9 \pm 9$ & $6 \pm 4$ & nS \\
\hline
\end{tabular}

Values are presented as arithmetic mean \pm SD. *: percentage of total lymphocytes; +: percentage of T-lymphocytes. BAL: bronchoalveolar lavage; NK: natural killer; ns: nonsignificant.

quotients of the same selected lymphocyte subpopulations and compared the two groups. Except for memory Tlymphocytes, which had a significantly lower BAL/blood quotient in the $\mathrm{CB}$ group, no significant differences were detected (data not shown).

\section{Lymphocyte proliferation}

The proliferative response of peripheral blood mononuclear cells (PBMCs) to stimulation with different antigens a)

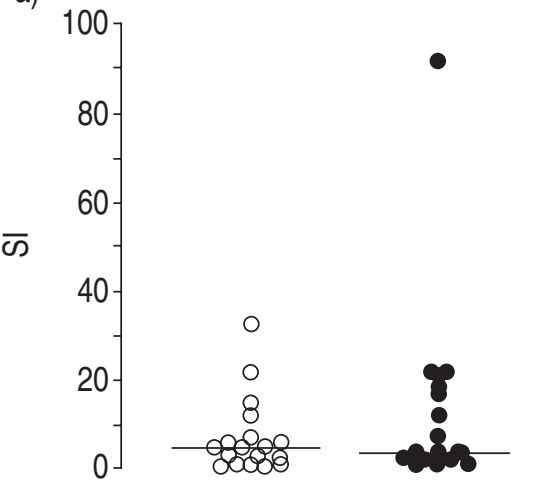

d)

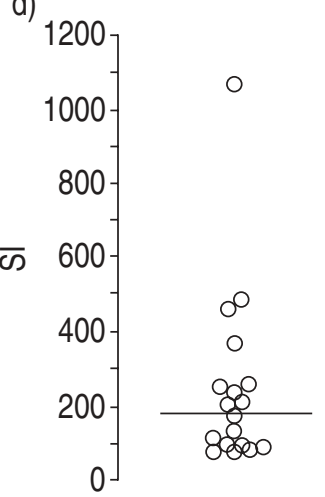

b)

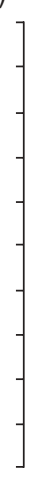

e)

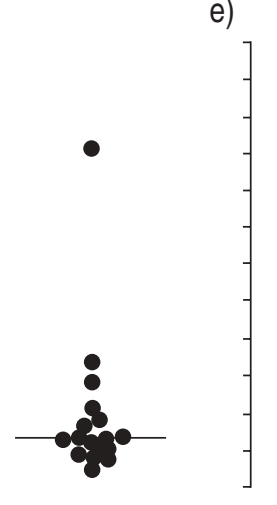

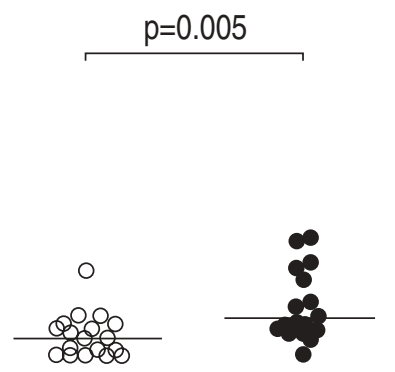

and mitogens is shown in figure 1. There was a significantly higher $(\mathrm{p}=0.005)$ proliferative response in the $\mathrm{CB}$ group after stimulation with diphtheria toxoid. There was no significant difference between the groups for any of the other antigens or mitogens, and no tendency or pattern separating the two groups could be detected in the lymphoproliferative responses. Stimulation with the superantigen SEA and the mitogen PHA resulted in prominent responses. Responses to the three antigens tetanus toxoid, diphtheria toxoid and PPD were much lower and responses to the monoclonal CD3 antibody were intermediate.

\section{Cytokine production}

Data of IL- 6 , IFN- $\gamma$ and TNF- $\alpha$ concentrations in supernatants from cultured PBMCs without and with stimulation with tetanus toxoid are presented in figures $2 \mathrm{a}-\mathrm{c}$. Some values were below the detection limit and three were above the upper limit. Values below the limit value are represented by half that value, and values above the upper limit by that value.

Stimulation with tetanus toxoid resulted in an increased concentration of TNF- $\alpha$ in both groups, with a significantly higher concentration in the $C B$ group $(p<0.05)$. TNF- $\alpha$ levels without stimulation were also higher in the $\mathrm{CB}$ group, but this difference was not significant. Tetanus toxoid stimulation did not noticeably increase concentrations of IL- 6 and IFN- $\gamma$ in any group, nor were there any significant differences between the groups for these cytokines.

c)

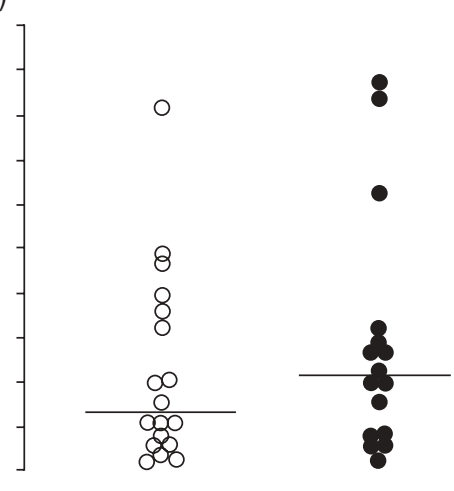

f)
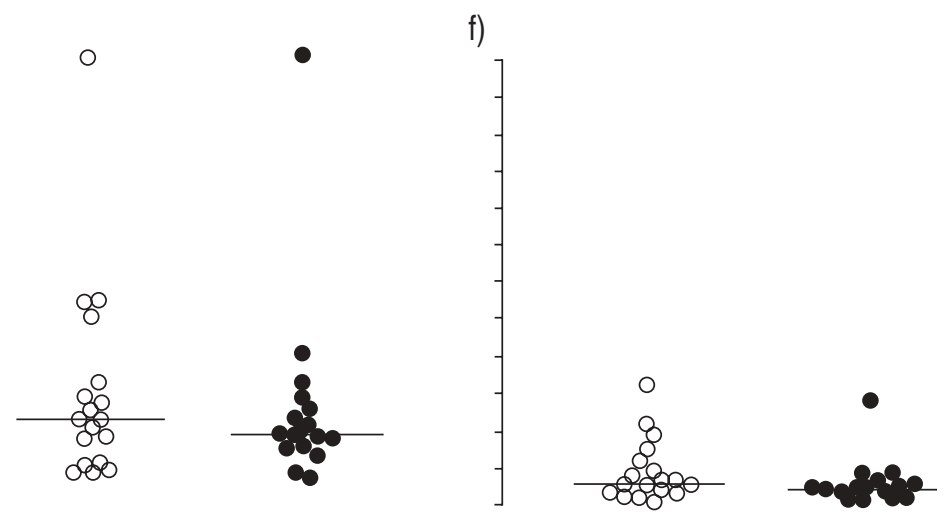

Fig. 1. - Proliferation of blood mononuclear cells from asymptomatic smokers $(\bigcirc)$ and chronic bronchitis patients ( $\bullet$ ) after stimulation with: a) tetanus toxoid; b) diphtheria toxoid; c) purified protein derivative; d) staphylococcus enterotoxin A; e) phytohaemagglutinin; and f) anti-CD3. Individual and median values of stimulatory index (SI) are shown. 


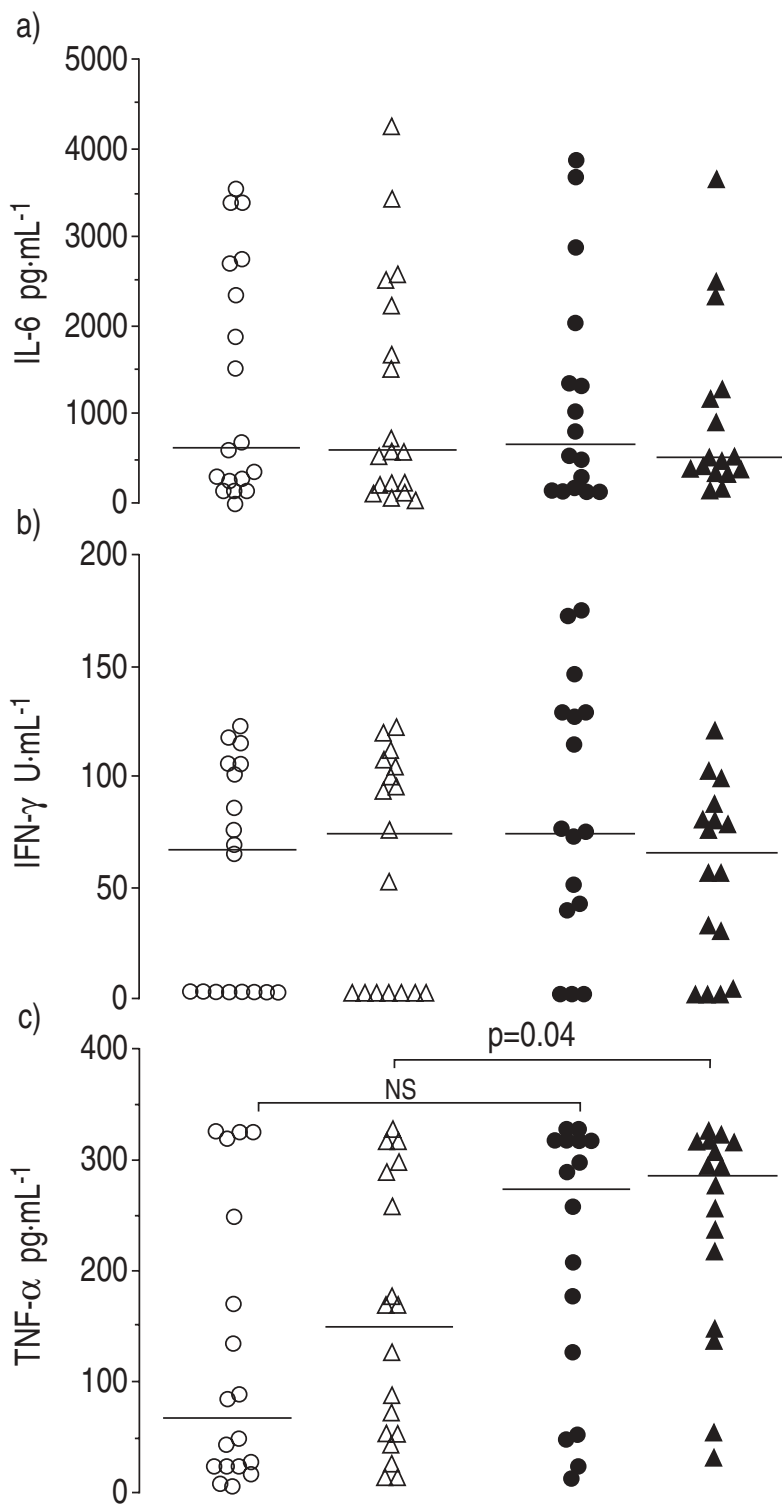

Fig. 2. - Concentrations of: a) interleukin-6 (IL-6), b) interferon- $\gamma$ (IFN- $\gamma$ ) and c) tumour necrosis factor- $\alpha$ (TNF- $\alpha$ ) in supernatants from blood mononuclear cell cultures without $(O, \bullet)$ and with $(\Delta, \mathbf{\Delta})$ stimulation with tetanus toxoid. Individual and median values are presented. $\bigcirc$, $\Delta$ : asymptomatic smokers; $\bullet, \mathbf{\Delta}$ : chronic bronchitis patients.

For IL-2, IL-4 and TGF- $\beta$, all values except one were below the detection limit of the assays. These cytokines were therefore not included in the analysis and tabulation.

\section{NK-cell activity assay}

The median fractions of lysed target cells were $20 \%$ (range $1-46 \%$ ) and 14\% (2-38\%) in the CB and AS groups, respectively. The difference was not statistically significant.

\section{Discussion}

In the present study we investigated different aspects of the immune system in a well-defined group of patients with $\mathrm{CB}$ and recurrent infectious exacerbations. Our aim was to search for possible changes in the immune system associated with recurrent infectious exacerbations in patients with $\mathrm{CB}$, and not attributable to smoking itself. Our results indicate that systemic and local immunity in $\mathrm{CB}$ patients with recurrent infectious exacerbations does not in any major way differ from that of asymptomatic smokers when smoking status is comparable. However, detailed analysis revealed some interesting findings.

The results of the serum Ig analyses indicate a possible connection between recurrent infectious exacerbations and lower levels of $\mathrm{IgG}_{3}$ in smokers with $\mathrm{CB}$, although no correlation was found between the number of exacerbations and $\mathrm{IgG}_{3}$ levels. An over-representation of $\mathrm{IgG}_{3}$ deficiency has previously been reported in patients with recurrent respiratory infections $[29,30]$, but it appears to be more common among nonsmoking patients than among smokers with $\mathrm{CB}$ and recurrent infectious exacerbations [30]. In studies of patients with chronic obstructive pulmonary disease (COPD), $\mathrm{IgG}_{1}$ and $\mathrm{IgG}_{2}$ deficiencies seem to be more frequent than $\mathrm{IgG}_{3}$ deficiency $[31,32]$. Results from these studies are difficult to compare with those of the present study, due to differences in patient selection. However, the possible connection between $\operatorname{IgG}_{3}$ deficiency and recurrent infectious exacerbations in smokers with $\mathrm{CB}$ needs further attention.

When comparing lymphocyte phenotypes in blood and BAL from $\mathrm{CB}$ patients with those from asymptomatic smokers, few if any indications of pathological changes related to susceptibility to infection were found in our CB patients. However, results of the flow cytometry analysis demonstrate major differences in the distribution of lymphocyte phenotypes between BAL and blood, with a higher fraction of T-cells, predominantly of the memory type (expressing CD45R0), and a lower fraction of B-cells in BAL compared with blood. These findings are in accordance with earlier findings in both smokers and nonsmokers [33, 34]. Furthermore, confirming and extending earlier observations [34], we found a much higher expression of common activation markers on T-cells in BAL compared with blood, with the expression of CD25 comparatively less pronounced than that of CD69 and HLADR. It appears as if the transformation of naive systemic T-cells (expressing CD45RA) to memory T-cells lining the alveolar surfaces coincides with an increase in surface expression of some activation markers, i.e. CD69 and HLA-DR, but not CD25, suggesting preactivation but not necessarily proliferation.

Results from previous studies on the effect of smoking on the proliferative response of PBMCs to mitogenic or antigenic stimulation are not conclusive [17, 35-37]. Proliferative responses of PBMCs from patients with $\mathrm{CB}$ have been investigated by ScHöNFELD et al. [38] and were found to be decreased to both mitogens (PHA, Concanavalin A) and an antigen (tetanus toxoid). However, no account of smoking status was given in their report. We found a significantly higher response to diphtheria toxoid in the $\mathrm{CB}$ group, but no differences for the other stimulators. Our results do not support the suggestion made by ScHöNFELD et al. [38] that patients with $\mathrm{CB}$ have impaired cell-mediated immunity.

The only difference in cytokine production found between our study groups was a significantly higher level of stimulated TNF- $\alpha$ production in the CB group. This is in line with several reports indicating a dysregulation of 
TNF- $\alpha$ production and release in patients with inflammatory airways disease. Significantly higher levels of TNF- $\alpha$ have been demonstrated in induced sputum from patients with COPD compared with both smoking and nonsmoking controls [39]. Furthermore, in two recent reports comparing weight-losing and weight-stable COPD patients, higher serum TNF- $\alpha$ levels [40] as well as higher stimulated blood monocyte production of TNF- $\alpha$ [41] were found in the weight-losing groups. Smoking alone has also been shown to influence TNF- $\alpha$ production. Increased production of TNF- $\alpha$ in lipopolysaccharide (LPS)-stimulated PBMCs from smokers as compared to those from nonsmokers has been reported [42], while on the other hand LPS-stimulated alveolar macrophages (AMs) from smokers seem to have impaired ability to release TNF- $\alpha$ compared to AMs from nonsmokers [43].

To conclude, in this extensive investigation of different aspects of immune function, we found only minor differences between smokers with chronic bronchitis and recurrent infectious exacerbations and asymptomatic smokers with comparable smoking habits. If major differences had been found, an extension of the present study comparing chronic bronchitis patients with and without recurrent infectious exacerbations and with similar smoking habits would have been of interest. Not only smoking but also presence of chronic bronchitis could then be ruled out as confounding factors. In light of the predominantly negative results of the present study, such an investigation seems unwarranted, with the possible exception of further study of immunoglobulin $\mathrm{G}$ subclasses and regulation of tumour necrosis factor- $\alpha$ production and release.

Acknowledgements: The authors would like to thank study nurse A-M. Hilmersson, biotechnician B-M. Essman and study monitor A-B. Löfroos for their excellent work in connection with this study.

\section{References}

1. Aronson MD, Weiss ST, Ben RL, Komaroff AL. Association between cigarette smoking and acute respiratory tract illness in young adults. JAMA 1982; 248: 181-183.

2. Marcy TW, Merril WW. Cigarette smoking and respiratory tract infection. Clin Chest Med 1987; 8: 381-391.

3. Holt PG. Immune and inflammatory function in cigarette smokers. Thorax 1987; 42: 241-249.

4. Smoking and immunity (editorial). Lancet 1990; 335: 1561-1563.

5. Mili F, Flanders WD, Boring JR, Annest JL, Destefano F. The association of race, cigarette smoking, and smoking cessation to measures of the immune system in middleaged men. Clin Immunol Immunopathol 1991; 59: 187200.

6. Tollerud DJ, Brown LM, Blattner WA, et al. Racial differences in serum immunoglobulin levels. J Clin Lab Anal 1995; 9: 37-41.

7. Burrows B, Halonen M, Berbee RA, Lebowitz MD. The relationship of serum immunoglobulin $\mathrm{E}$ to cigarette smoking. Am Rev Respir Dis 1981; 124: 523-525.

8. Mills CM, Hill SA, Marks S. Altered inflammatory responses in smokers. BMJ 1993; 307: 911.

9. Anderson K, Morrison SM, Bourke S, Boyd G. Effect of cigarette smoking on the specific antibody response in pigeon fanciers. Thorax 1988; 43: 798-800.

10. Winter AP, Follet EAC, McIntyre J, Stewart J, Symington
IS. Influence of smoking on immunological responses to hepatitis B vaccine. Vaccine 1994; 12: 771-772.

11. Ginns LC, Ryu JH, Rogol PR, Sprince NR, Oliver LC, Larsson CJ. Natural killer cell activity in cigarette smokers and asbestos workers. Am Rev Respir Dis 1985; 131: 831-834.

12. Phillips B, Marshall E, Brown S, Thompson JS. Effect of smoking on human natural killer cell activity. Cancer 1985; 56: 2789-2792.

13. Takeuchi M, Nagai S, Izumi T. Effect of smoking on natural killer cell activity in the lung. Chest 1988; 94: 688-693.

14. Silverman NA, Potvin C, Alexander JC, Chretien PB. In vitro lymphocyte reactivity and T-cell levels in chronic cigarette smokers. Clin Exp Immunol 1975; 22: 285-292.

15. Daniele RP, Dauber JH, Altose MD, Rowlands DT, Gorenberg DJ. Lymphocyte studies in asymptomatic cigarette smokers. A comparison between lung and peripheral blood. Am Rev Respir Dis 1977; 116: 997-1005.

16. Petersen BH, Steimel LF, Callaghan JT. Suppression of mitogen-induced lymphocyte transformation in cigarette smokers. Clin Immunol Immunopathol 1983; 27: 135-140.

17. Hughes DA, Haslam PL, Townsend PJ, Turner-Warwick $M$. Numerical and functional alterations in circulatory lymphocytes in cigarette smokers. Clin Exp Immunol 1985; 61: 459-466.

18. Costabel U, Bross KJ, Reuter C, Rühle K-H, Matthys H. Alterations in immunoregulatory T-cell subsets in cigarette smokers; a phenotypic analysis of bronchoalveolar and blood lymphocytes. Chest 1986; 90: 39-44.

19. Ginns LC, Miller LG, Goldenheim PD, Goldstein G, Bria WF. Alterations in immunoregulatory cells in lung cancer and smoking. J Clin Immunol 1982; 2: S90-S94.

20. Miller LG, Goldstein G, Murphy M, Ginns LC. Reversible alterations in immunoregulatory $\mathrm{T}$ cells in smoking. Chest 1982; 82: 526-529.

21. Fletcher C, Peto R. The natural history of chronic airflow obstruction. BMJ 1977; 1: 1645-1648.

22. Standards for the diagnosis and care of patients with chronic obstructive pulmonary disease (COPD) and asthma. Official statement of the American Thoracic Society. Am Rev Respir Dis 1987; 136: 225-244.

23. Boman G, Bäcker U, Larsson S, Melander B, Wåhlander L. Oral acetylcysteine reduces exacerbation rate in chronic bronchitis: report of a trial organized by the Swedish Society for Pulmonary Diseases. Eur J Respir Dis 1983; 64: 405-415.

24. Quanjer PH. Standardized lung function testing. Report working party standardization lung function tests. European Community for Coal and Steel. Bull Europ Physiopath Respir 1983; 19 (Suppl. 5): 1-95.

25. Oxelius V-A. IgG subclass levels in infancy and childhood. Acta Paediatr Scand 1979; 68: 23-27.

26. Vajdy M, Lycke N. Stimulation of antigen-specific T- and B-cell memory in local as well as systemic lymphoid tissues following oral immunization with cholera toxin adjuvant. Immunology 1993; 80: 197-203.

27. Linder H, Engberg I, Hoschützky H, Mattsby-Baltzer I, Svanborg C. Adhesion-dependent activation of mucosal IL-6 production. Infect Immun 1991; 59: 4357-4362.

28. Hellstrand K, Asea A, Dahlgren C, Hermodsson S. Histaminergic regulation of NK-cells. Role of monocytederived reactive oxygen metabolites. J Immunol 1994; 153: 4940-4947.

29. Söderström T, Söderström R, Avazini A, Brandtzaeg P, Karlsson G, Hanson LÅ. Immunoglobulin G subclass deficiencies. Int Arch Allergy Appl Immunol 1987; 82: 476-480.

30. Popa V, Kim K, Heiner DC. IgG deficiency in adults with 
recurrent respiratory infections. Ann Allergy 1993; 70: 418-424.

31. O'Keeffe S, Gzel A, Drury R, Cullina M, Geally J, Finnegan P. Immunoglobulin $\mathrm{G}$ subclasses and spirometry in patients with chronic obstructive pulmonary disease. Eur Respir J 1991; 4: 932-936.

32. Riise GC, Larsson S, Larsson P, Jeansson S, Andersson BA. The intrabronchial microbial flora in chronic bronchitis patients. A target for $\mathrm{N}$-acetylcysteine therapy? Eur Respir J 1994; 7: 94-101.

33. Saltini C, Kirby M, Trapnell BC, Tamura N, Crystal RG. Biased accumulation of T lymphocytes with "memory"type CD45 leukocyte common antigen gene expression on the epithelial surface of the human lung. $J$ Exp Med 1990; 171: 1123-1140.

34. Ancochea J, González A, Sánchez MJ, Aspa J, LópezBotet M. Expression of lymphocyte activation surface antigens in bronchoalveolar lavage and peripheral blood cells from young healthy subjects. Chest 1993; 104: 32-37.

35. Anderson D, Jenkinson PC, Dewdney RS, Francis AJ, Godbert P, Butterworth KR. Chromosome aberrations, mitogen-induced blastogenesis and proliferative rate index in peripheral lymphocytes from 106 control individuals of the U.K. population. Mutat Res 1988; 204: 407-420.

36. Wolfe WH, Miner JC, Michalek JE. Immunological parameters in current and former US Air Force personnel. Vaccine 1993; 11: 545-547.
37. Meliska CJ, Stunkard ME, Gilbert DG, Jensen RA, Martinko JM. Immune function in cigarette smokers who quit smoking for 31 days. J Allergy Clin Immunol 1995; 95: 901-910.

38. Schönfeld N, Remy N, Bartmann P, Wahn U, Loddenkemper R. In vitro Untersuchungen zur cellulären Immunität bei chronischen Bronchitikern mit und ohne Kortiko-steroidmedikation. Pneumologie 1992; 46: 179-182.

39. Keatings VM, Collins PD, Scott DM, Barnes PJ. Differences in interleukin- 8 and tumor necrosis factor- $\alpha$ in induced sputum from patients with chronic obstructive pulmonary disease or asthma. Am J Respir Crit Care Med 1996; 153: 530-534.

40. Francia MD, Barbier D, Mege JL, Orehek J. Tumor necrosis factor-alpha levels and weight loss in chronic obstructive pulmonary disease. Am J Respir Crit Care Med 1994; 150: 1453-1455.

41. de Godoy I, Donahoe M, Calhoun WJ, Mancino J, Rogers RM. Elevated TNF- $\alpha$ production by peripheral blood monocytes of weight-losing COPD patients. Am J Respir Crit Care Med 1996; 153: 633-637.

42. Tappia PS, Troughton KL, Langley ES, Grimble RF. Cigarette smoking influences cytokine production and antioxidant defences. Clin Sci (Colch) 1995; 88: 485-489.

43. McCrea KA, Ensor JE, Nall K, Bleecker ER, Hasday JD. Altered cytokine regulation in lungs of cigarette smokers. Am J Respir Crit Care Med 1994; 150: 696-703. 